Article

\title{
Diversity, Conflict and Growth: Theory and Evidence
}

\section{Gerald Schneider $^{1, *}$ and Nina Wiesehomeier ${ }^{2}$}

1 Fachbereich Politik- und Verwaltungswissenschaft, Lehrstuhl für Internationale,University of Konstanz, Fach 86, Universitätsstr.10, 78457 Konstanz, Germany

2 Instituto de Ciências Sociais da Universidade de Lisboa, Av. Aníbal de Bettencourt, 9, Lisbon 1600-189, Portugal; E-Mail: Nina.Wiesehomeier@ics.ul.pt

* Author to whom correspondence should be addressed; E-Mail: Gerald.Schneider@uni-konstanz.de; Tel.: +49-7531-88-3081; Fax: +49-7531-88-2774.

Received: 1 April 2010; in revised form: 4 August 2010 / Accepted: 14 May 2010 /

Published: 31 August 2010

\begin{abstract}
This article re-examines recent studies that link different forms of social diversity - ethnic polarization and fractionalization - to underdevelopment and an increased risk of civil war. We review theoretical arguments in favor of a connection between diversity and these social outcomes and discuss the inter-linkage between economic growth and internal conflict in situations of extreme diversity. Our analysis confirms that the relationship between ethnic polarization and civil war is ambiguous and depends on the use of civil war incidence or civil war onset as an outcome variable. Furthermore, fractionalization rather than polarization seems to be negatively related to economic growth.
\end{abstract}

Keywords: civil war; development; polarization; fractionalization

\section{Introduction}

Throughout the past decade, the social and political implications of social diversity have received widespread attention in economics and the social sciences. While management theorists and sociologists often see diversity as an asset to a firm or a society (e.g., [1]), political scientists and economists, conversely, often warn about the dangers of an increasing fragmentation or polarization of a country. The best known caveat against the alleged perils of diversity is Huntington's [2] essay The Clash of Civilizations and the Remaking of World Order, in which the late Harvard academic painted 
the picture of an increasing risk of conflict between incompatible "civilizations" such as the West and the Islamic world. Although careful analyses of the historical and statistical evidence have contradicted this thesis (e.g., $[3,4]$ ), it has considerably shaped the popular and, to some extent, also the academic discussion, on the political and economic effects that relevant social, economic or religious cleavages may have.

Social scientists have, however, moved beyond this pessimistic backdrop through the development of sophisticated arguments that link different facets of social heterogeneity to various social outcomes. This article evaluates recent conceptual innovations and empirical findings on the effects of diversity on the risk of internal war and on economic growth. In this article we contrast the two most frequently used diversity indicators, "fractionalization" and "polarization", which according to recent studies can be seen as explanations of both violent internal conflict and economic stagnation. To make this discussion more specific, we discuss the advantages and disadvantages of these competing concepts through an evaluation of two frequently cited studies by Montalvo and Reynal-Querol (henceforth MRQ) [5,6]. These authors have broken new ground in the literature by arguing, and demonstrating empirically, that especially one form of diversity, polarization, increases the risk of civil war and also has a negative impact on the provision of public goods and the growth prospects of a country. Thus, we believe that this pioneering work provides an excellent point of departure to re-examine these findings and highlight problems in the study of diversity. To this end, we first identify theoretical problems that emerge when we try to link the different facets of diversity to a wide range of social ills. Empirically, we develop a research design that follows as closely as possible the two exemplary articles that guide our study. The re-examination shows that well-founded alterations of the research design lead to different results. We particularly use "onset" rather than "incidence" as a measure of the outcome variable "civil war"; classify groups differently; and assess the influence of polarization on economic growth drawing on a prominent model developed by Easterly and Levine [7]. The results suggest that the relationship between polarization and conflict is ambiguous and that it might also be rather fractionalization and thus fragmentation that hinders economic growth. The article concludes with the recommendation that the study of diversity in the social sciences should rely on empirical indicators that are more closely linked to rigorous theoretical reasoning and that move away from the conviction that one particular measure of diversity can be successfully applicable to all contexts.

\section{Theory and Measurement of Diversity in the Social Sciences}

Diversity is a vague enough term to invite all sorts of expectations about the possible benefits and ills it may bring about. In our view, such general discussions about the pros and cons of social heterogeneity are misleading, as we need to be specific about which form of diversity we try to link to a particular social outcome. The most frequently used diversity indicator is the fractionalization index which stems from the Hirschman-Herfindahl measure of concentration (compare with [8]). Formally, fractionalization $(\mathrm{F})$ is defined as follows:

$$
F=\sum_{i=1}^{N} \pi_{i}\left(1-\pi_{i}\right)
$$

where $\pi$ stands for the relative size of the relevant social groups, be they ethnically, religiously or linguistically defined. 
Ethnic fractionalization has played a key role in research on economic growth and in public economics. Easterly and Levine ([7], p. 1241) argue that a high level of "ethnic diversity is closely associated with low schooling, underdeveloped financial systems, distorted foreign exchange markets, and insufficient infrastructure". Collier [9] conversely maintains that a country's institutional setting is able to mediate such adverse effects of fragmentation. In his view, the negative impact of fractionalization on development is restricted to autocratic countries. Alesina and LaFerrara [10] examine this claim, yet find only weak support for it. Their empirical results show that rich countries are better able to manage diversity than poorer ones.

In recent years, diversity arguments have also increasingly shaped the area of conflict research, which for decades has been a strong subfield of political science and to which a growing number of economists contribute. Ellingsen's [11] pioneering study regressed domestic civil unrest on various indicators and found that multiethnicity was a powerful determinant of domestic conflict. Furthermore, her article shows that the relationship between the number of groups within a society and the risk of civil war is of a curvilinear nature, with an increasing propensity towards war in a country with several compared to a few or many groups. This is similar to the argument of Collier and Hoeffler [12]. They demonstrate that the dominance of one strong group in heterogeneous countries is associated with a higher probability of war. Collier [9] qualifies societies as "dominated" if the largest group contains between 45 and $90 \%$ of the overall population. In contrast, Hegre et al. [13] find that fractionalization is linked to an increased risk of civil war. The frequently cited study by Fearon and Laitin [14] does not lend empirical support to the thesis that fragmentation increases the risk of an internal war; the meta-evaluation of Hegre and Sambanis [15] supports this result.

It can, in our view, be easily explained theoretically why the link between fractionalization and conflict is unclear. To start with, consider the case in which every social group $\pi_{\mathrm{i}}$ were to split into $k$ equally sized subgroups, each now with size $\pi_{i} / k$. Since these smaller groups do not have the same resource base as the larger ones, we cannot assume that they would bother to engage in an internal war as they could not credibly threaten a larger group with the usage of armed force. Similarly, it is unclear as to why societies that are highly fractionalized should suffer from reduced economic development. While a growing number of groups increase the coordination costs in a society, it also fuels the competition between these groups and, in the absence of any institutional considerations, the efficiency of an economy ( $c f$. [10]). In other words, increasing fractionalization of a country can be good and bad for the development of a country. As a result, the link between fragmentation and economic growth is theoretically as underspecified as the one with civil war.

Given these theoretical conjectures and empirical contradictions, it is unsurprising that students of diversity have developed alternative indices. Particularly the concept of polarization has gained prominence in the field through the development of axiomatic measures by Esteban and Ray [16] that the authors applied to the formal analysis of social conflict in a later paper [17]. Based on four straightforward axioms and on Esteban and Ray [16], Duclos and colleagues [18] have developed a measure of polarization that depends on the separate contributions of alienation and identification and on their joint co-movement. This leads to a measure that is proportional to the sum of all effective antagonisms within a society ([16], p. 831). 
Formally, the polarization measure developed by Duclos et al. [18] for a continuous distribution $F$ can be written as

$$
P(F)=\iint f(x)^{1+\alpha} f(y)|x-y| d x d y, \quad 0.25 \leq \alpha \leq 1
$$

In Equation (2), $\mathrm{x}$ and $\mathrm{y}$ are for instance individual ideological positions or income levels. The model presumes that alienation is monotonically growing in the distance $|x-y|$. Alternatively, the $P(F)$ measure can also be written as the product of three components

$$
P(F)=a(F) i(F, \alpha)[1+\rho]
$$

where $a(F)$ stands for average alienation, $i(F, \alpha)$ for average identification and $\rho$ for the normalized covariance between identification and alienation [19]. The measurement of polarization identifies whether the distribution of a particular societal attribute like income or ideology displays group modes. Typical inequality measures like the Gini-index fail to capture this feature. It should nevertheless be noted that polarization and inequality (Gini) coincide if $\alpha$ is 0 . The restriction $\alpha \geq 0.25$ is crucial. It is only with this assumption that (2) behaves differently in comparison to inequality indices [20].

Reynal-Querol ([23,24], see also [5]) has, based on Esteban and Ray [16], introduced a new measure of polarization (henceforth RQ). It can be summarized as follows:

$$
R Q=4 \sum_{i=1}^{N} \pi_{i}^{2}\left(1-\pi_{i}\right)
$$

Note that, similar to fractionalization, the RQ measure grows through a split of a group into smaller units if the original group is smaller or equal to $70 \%$ of the overall population [25]. In the absence of detailed individual-level information for a large number of countries, the polarization measure used by MRQ, and originally proposed by Reynal-Querol [23], differs from the Esteban and Ray [17] index by only considering binary attributes of an individual, for instance whether he or she belongs to a group or not. As a consequence, the animosity between groups is identical, which seems at present highly unlikely if we compare the typically relatively low level of hostility between Catholics and Protestants in the past decades with the much less harmonious relations between Muslims and Christians in many countries. Furthermore, the index does not take into account the possible variance of other relevant attributes of a person like income or ideology within a particular group or the varying attachment to a group among its members.

Esteban and Ray [17] show, as indicated, in a rentseeking model that the level of conflict in a society should be largest when the population, which can be classified according to some interval-level measures, is split symmetrically into two equally powerful groups. Reynal-Querol [23] and Montalvo and Reynal-Querol [5] demonstrate for their measures that "a two-point symmetric distribution of population maximizes conflict" ([5], p. 798). Note, however, that the conceptualization of conflict in these models avoids a clear distinction between investment in conflict instruments like weapons or soldiers and the costs of fighting. In other words, the extant rentseeking models of conflict do not consider the possible deterrent effect that armament might have. Standard models in international relations show that an equality of resources between two contending sides might lead to a precarious peace as the competing poles are able to deter each other from using force (e.g., [26]). Hence, the conflict potential in bipolar societies might be very large, but such situations must not necessarily be linked to an increased number of conflict onsets. A more recent rentseeking model by Esteban and 
Ray [25] that explores the impact of fractionalization and polarization on conflict in detail confirms this. They "expect the overall degree of conflict to be maximal in societies with intermediate levels of polarization" ([25], p. 180).

We also do not see a clear link between high degrees of polarization and economic development. On the contrary, bipolar societies have fewer coordination problems than highly fragmented ones. One way in which bi-polarization could cause underdevelopment is through the domination of one strong group by another powerful, but parasitic force. This is for instance often the case in countries such as Ruanda where the domineering group typically excludes the competing ethnicity from the government and tries to hold on to power in economically adverse times through repression [27]. The inclusion of such considerations would, however, make it necessary to study the inter-linkage between polarization and social outcomes through institutionalist lenses and to particularly examine how inclusive governments are (cf. [28]). We will come back on these possible extensions of the analysis of diversity in the conclusion of this article.

\section{Polarization, Fractionalization and Conflict}

The study of the social outcomes of diversity does not only need sound theoretical arguments, it equally has to be based on transparent operational definitions and case selection criteria. Before we present our results, this section discusses how key contributions to the applied study of diversity have dealt with these research design issues. The starting point for any empirical study in this area is the selection of relevant social groups. Until the 1990s, most work on country-level diversity relied on the Soviet Atlas Norodov [29]. Since then, Fearon [30], Alesina et al. [31], and Montalvo and Reynal-Querol [5,6] have improved the empirical basis by including information from a variety of additional sources. To this growing list of diversity data sets, Cederman et al. [32] adds an expert survey on relevant ethnic groups that tracks power shifts in ethnic political constellations.

The majority of authors working on ethnicity and related cleavages agree with Vanhanen [33] that only the most important ethnic divisions should be taken into account. In a very comprehensive article, Fearon [30] presents a list of 822 groups in 160 countries that had over half a million inhabitants in 1990. Apart from language, Fearon ([30], p. 210) includes other "criteria distinguishing groups, provided that the groups are locally understood as (primarily) descent groups and are locally viewed as socially or politically most consequential". Similarly Alesina and colleagues [31] compile information on 650 distinct ethnic groups in 190 countries and take into account "not only language, but also other cleavages such as racial characteristics" ([31], p. 157). Both sources provide a fractionalization measure but also data on the individual groups on which they are based. Unfortunately, Montalvo and Reynal-Querol offer us a ready-made data set of diversity measures for 138 countries and an unknown number of groups. Thus, after the initial replication of the results originally presented in the articles that we evaluate for illustrative purposes, the empirical analyses that we will present in the subsequent sections rely on the Fearon data set using the RQ polarization formula [34].

In their studies, Montalvo and Reynal-Querol [5] have found encompassing evidence that polarization - either ethnic or religious - rather than fractionalization increases the risk of civil war and conclude that "...the weak explanatory power of ethnic heterogeneity on the incidence of civil wars found by several recent studies is due to the use of an index of fractionalization instead of an 
index of polarization" ([5], p. 812). Hence, coding decisions for such indicators are of utter importance and we therefore compare in the following our measures based on the Fearon data with the Reynal-Querol diversity data. In the construction of their indices, MRQ rely on standard sources like the World Christian Encyclopedia (WCE). The classification particularly focuses on the ethno-linguistic families detailed in WCE which considers the nearness of languages and of racial, ethnic, cultural and cultural-area characteristics. In general, our measures, based on Fearon and those used by MRQ, are quite similar, but we believe that the differences that we do see are due to coding decisions [35]. However, since the authors do not provide a listing of the individual groups that went into their ethnicity measures, we cannot assess the data regarding ethnic groups. To illustrate our concern, we therefore describe some decisions the authors make regarding the definition of religious groups that differ from ours. These definitions can be found in the articles under consideration.

For instance, we think it is debatable to consider Animist religions and syncretic cults as a category of their own, but to merge Protestants and Catholics into a single group dubbed "Christians". During the past few years, Protestantism has been rapidly expanding in Latin America, and Protestants are demanding more equal treatment. Especially in Brazil, tensions between the Latin American Catholic Church and Protestants are visible [36]. Furthermore, although tensions between Catholics and Protestants have generally weakened throughout the past decades in the developed world, political sociologists still consider this to be an important and newly intensified cleavage [37]. At least in Great Britain this religious antagonism has fuelled the violence that beset Northern Ireland from the 1960s to the end of the 1990s.

The categorization of syncretic cults is more difficult. In general, historians of religion agree that all religions are more or less syncretistic, as Syncretism is defined as a process through which elements of one religion are assimilated into another one [38-40]. It is true, as viewed by Montalvo and Reynal-Querol [5], that in Latin America a considerable part of the population, mainly indigenous people, is affiliated with, for example, Catholicism while they are practicing what is betoken as Syncretism. But the term denotes by definition the mixing of religious elements and traditions and very often refers to the adaptation of the imported religion into a specific regional context. Hence, the term emphasizes similarities rather than differences [42]. Because of these cultural adaptations and modifications, Syncretism is contested as a legitimate category among scholars of religion [44]. The elusiveness of this concept pertains to the problem that people who mix elements of various religions may not do so deliberately and rarely call themselves "Syncretists" [45,46]. In other words, it remains unclear why we should count such cults as a separate religion.

A similar but distinct case is Animism. Animist groups in Africa and African religions in general have absorbed many elements from Christianity and Islam. But in contrast to Syncretism, the term "Animism" is widely used and receives a clear attribution as "belief in spiritual beings who are concerned with human affairs and capable of intervening in them" [47]. In addition, African countries have a richer tradition in fusing the political and the religious. Claffey [48] observes, in this vein, that African leaders generally look for legitimization within the spiritual sphere and that basic relations with the primary church are not conflict-free. This, in our opinion, justifies the incorporation of traditional religions rather than Animism as a separate category.

Our alternative measure of religious polarization takes the differences between "Syncretism" and "Animism" into account and considers, in line with Fearon, only the most consequential divisions 
within a society. Thus, the measure we use in the following breaks up "Christians" into subgroups, does not code Syncretic cults, but treats traditional religions in the case of Africa as a separate category; this is in accordance with the coding decision underlying the Fearon data set. We can illustrate with some examples that seemingly trivial coding decisions are not innocuous. Based on our definition of religion division, we attribute a religion polarization value of 0.76 instead of 0.14 to the United Kingdom, as it can be found in the data set of Montalvo and Reynal-Querol. Peru, which was shaken throughout the 1980s and 1990s by the revolt of the Marxist Sendero Luminoso, receives a religion polarization value of 0.36 instead of 0.88 .

Another way in which our research design differs from the original investigation is the definition of our dependent variable. The original calculation uses the "incidence" rather than the "onset" of civil war as the phenomenon of interest. Note that the use of the former concept stands in sharp contrast to the overwhelming majority of current studies on the causes of civil war, like the contributions made by Fearon and Laitin [14] and Collier and Hoeffler [12]. Current studies tend to concentrate on the "onset" of civil wars, and there is good reason to do so. Studying interstate wars, Beck [49] points out that the use of "onset" rather than "incidence" is not just a matter of taste. First, the factors that contribute to the launching of a social conflict might not necessarily be the same as the ones that keep feeding it. Second, the risk that a civil war continues is much higher than the case of a war outbreak. To resolve this problem, Beck ([49], p. 171) recommends that the model specification should contain variables that "would allow the probability of a dispute to be vastly higher if it immediately follows a previous year with a dispute." Other escape routes that he recommends are the use of transition models or event history models for that matter.

In the context of intrastate wars, Elbadawi and Sambanis [50] make a similar point and distinguish between onset and duration of civil wars. Brandt et al. [51] argue that the study of the duration of civil wars is concerned with the subset of countries that already have fallen victim to a conflict outbreak. In other words, it is unreasonable to expect that the same features that increase the risk of conflict similarly keep the flames of conflict burning once a war has erupted. Table 1 illustrates that using the incidence variable changes the sample of cases considerably. As we will show below, the usage of this indicator, and not the more commonly used onset variable, is one of the reasons why Montalvo and Reynal-Querol obtain results in favor of their polarization conjecture. Out of the 127 incidences of civil war studied by Montalvo and Reynal-Querol, 47 are onsets. 25 of these onsets continued over the next five-year-period. Hence, the risk that a conflict persists is much larger than the chance that a country experiences a conflict onset in the first place. As illustrations of wars with a duration of more than five years, consider, for instance, the conflicts we have seen in Southern Sudan or Angola.

If we use the incidence variable, the same conflict repeatedly reappears in the sample. This multiple counting of the exact same cases is as grave as the diversity variables hardly changing over time. To show that the specifications of the dependent variable make a statistical difference, we use both 'incidence' and 'onset' as outcome variables in our evaluation of the MRQ results. 
Table 1. Civil war onset $v s$. incidence as the dependent variable. The total of 780 refers to the number of observations of the model estimated in Table 2 column (2).

\begin{tabular}{lc|cc|} 
& & \multicolumn{2}{|c}{ Onset } \\
Continued in & & Yes & No \\
\cline { 2 - 4 } 5-year period & No & 25 & 733 \\
\cline { 2 - 4 } & & 22 & - \\
\hline
\end{tabular}

With respect to time dependence, we will heed Beck's second advice and use an event-history approach after assessing the risk of civil war with the help of yearly data and by controlling for dynamics. Event history models are appropriate if one understands an individual war as a sickness to which a country might fall victim at a single point of time rather than repeatedly, like the models by Montalvo and Reynal-Querol implicitly suggest. In conflict research, the usage of duration models is common practice. MRQ have relied on this methodology and show that ethnically polarized countries endure longer wars [52]. Such an undertaking requires, however, a different theory as the factors that cause a certain sickness are, as indicated, not necessarily the same as ones that are responsible for its duration. We opted for a country-year frame also because most covariates used in MRQ are available at this level of temporal aggregation and the fractionalization and polarization measures used in MRQ and our evaluation are almost time invariant.

Regarding the relationship between polarization and development, MRQ refer the reader to a different publication [6] in which they establish an indirect negative influence of ethnic polarization on growth via the positive impact of this factor on civil war. Therefore, as a last test we reexamine this finding using the seminal study of Easterly and Levine [7] as the base line model on how fractionalization undermines economic growth; adding our indices to their setup for ethnic and religious fractionalization and polarization (for a similar application see Valsecchi [53]).

As mentioned above, after the initial replication, we rely on the Fearon data set using the RQ formula to calculate ethnic and religious polarization. This means in particular that in Table 2-the table reporting the results for the five year periods - we rely on the covariates provided by MRQ (GDP per capita, population size, primary commodity export, percentage of mountainous terrain in a country, noncontiguous states, democracy, and data on ethnic and religious divisions) and only alter our definition of the dependent variable [54]. Table 3 and Table 4 present the models in which the country-year is the unit of analysis. We control the influence of the same covariates as in the previously presented calculations, but use the Fearon data for the operationalization of our diversity measures. Again, the tables provide the results across different definitions of the dependent variable [55]. 
Table 2. Civil War, Fractionalization and Polarization (Five year periods).

\begin{tabular}{|c|c|c|c|c|c|c|}
\hline & $\begin{array}{c}\text { Published } \\
\text { (1) } \\
\text { PRIOcw }\end{array}$ & $\begin{array}{c}(2) \\
\text { PrioCW } \\
\text { Onset } \\
\end{array}$ & $\begin{array}{c}(3) \\
\text { Onset } 25\end{array}$ & $\begin{array}{c}\text { Published } \\
(4) \\
\text { PRIOcw }\end{array}$ & $\begin{array}{c}(5) \\
\text { PrioCW } \\
\text { Onset } \\
\end{array}$ & $\begin{array}{c}(6) \\
\text { Onset } 25\end{array}$ \\
\hline LGDPC & $\begin{array}{c}-0.419 * \\
(0.235)\end{array}$ & $\begin{array}{l}-0.186 \\
(0.257)\end{array}$ & $\begin{array}{c}-0.497 * * * \\
(0.162)\end{array}$ & $\begin{array}{l}-0.328 \\
(0.291)\end{array}$ & $\begin{array}{l}-0.292 \\
(0.233)\end{array}$ & $\begin{array}{c}-0.664 * * * \\
(0.149)\end{array}$ \\
\hline LPOP & $\begin{array}{c}0.399^{* *} \\
(0.181)\end{array}$ & $\begin{array}{c}0.331 * * \\
(0.149)\end{array}$ & $\begin{array}{c}0.259 * * \\
(0.124)\end{array}$ & $\begin{array}{c}0.438 * * * \\
(0.146)\end{array}$ & $\begin{array}{c}0.426^{* * *} * \\
(0.140)\end{array}$ & $\begin{array}{c}0.337 * * * \\
(0.105)\end{array}$ \\
\hline PRIMEXP & $\begin{array}{l}-1.073 \\
(1.867)\end{array}$ & $\begin{array}{l}-0.441 \\
(1.553)\end{array}$ & $\begin{array}{l}1.614 * \\
(0.940)\end{array}$ & $\begin{array}{l}-0.354 \\
(1.713)\end{array}$ & $\begin{array}{c}0.463 \\
(1.648)\end{array}$ & $\begin{array}{c}2.416^{* *} \\
(0.942)\end{array}$ \\
\hline MOUNTAINS & $\begin{array}{l}-0.002 \\
(0.009)\end{array}$ & $\begin{array}{c}0.001 \\
(0.012)\end{array}$ & $\begin{array}{c}0.008 \\
(0.005)\end{array}$ & $\begin{array}{c}0.002 \\
(0.009)\end{array}$ & $\begin{array}{c}0.000 \\
(0.010)\end{array}$ & $\begin{array}{c}0.006 \\
(0.004)\end{array}$ \\
\hline NONCONT & $\begin{array}{c}0.290 \\
(0.597)\end{array}$ & $\begin{array}{c}0.248 \\
(0.556)\end{array}$ & $\begin{array}{l}0.616^{*} \\
(0.351)\end{array}$ & $\begin{array}{c}0.308 \\
(0.625)\end{array}$ & $\begin{array}{c}0.382 \\
(0.599)\end{array}$ & $\begin{array}{l}0.656^{*} \\
(0.390)\end{array}$ \\
\hline DEMOCRACY & $\begin{array}{c}0.034 \\
(0.365)\end{array}$ & $\begin{array}{l}-0.287 \\
(0.469)\end{array}$ & $\begin{array}{l}-0.076 \\
(0.283)\end{array}$ & $\begin{array}{c}0.017 \\
(0.362)\end{array}$ & $\begin{array}{l}-0.320 \\
(0.478)\end{array}$ & $\begin{array}{l}-0.045 \\
(0.284)\end{array}$ \\
\hline ETHPOL & $\begin{array}{c}2.289 * * \\
(1.026)\end{array}$ & $\begin{array}{c}0.514 \\
(1.108)\end{array}$ & $\begin{array}{c}0.852 \\
(0.742)\end{array}$ & - & - & - \\
\hline ETHFRAC & $\begin{array}{c}0.178 \\
(0.916)\end{array}$ & $\begin{array}{c}1.368 \\
(1.057)\end{array}$ & $\begin{array}{c}0.560 \\
(0.720)\end{array}$ & - & - & - \\
\hline RELPOL & - & - & - & $\begin{array}{c}3.903 * * \\
(1.983)\end{array}$ & $\begin{array}{l}2.975^{*} \\
(1.725)\end{array}$ & $\begin{array}{c}1.488 \\
(1.313)\end{array}$ \\
\hline RELFRAC & - & - & - & $\begin{array}{c}-4.972 * \\
(3.008)\end{array}$ & $\begin{array}{l}-3.887 \\
(2.709)\end{array}$ & $\begin{array}{l}-2.855 \\
(2.014)\end{array}$ \\
\hline Constant & $\begin{array}{c}-6.299 * * \\
(3.140)\end{array}$ & $\begin{array}{c}-7.574 * * \\
(3.442)\end{array}$ & $\begin{array}{l}-3.345 \\
(2.244) \\
\end{array}$ & $\begin{array}{c}-6.897 * * \\
(3.047)\end{array}$ & $\begin{array}{c}-7.762 * * \\
(3.347)\end{array}$ & $\begin{array}{l}-2.574 \\
(2.141)\end{array}$ \\
\hline Observations & 846 & 780 & 760 & 846 & 780 & 760 \\
\hline $\mathrm{N}^{\mathrm{o}}$ of countries & 117 & 115 & 115 & 117 & 115 & 115 \\
\hline Pseudo R2 & 0.122 & 0.0868 & 0.0853 & 0.110 & 0.0813 & 0.0817 \\
\hline
\end{tabular}

NOTE: Logit models with either civil war incidence or onset as the dependent variable and country five-year periods as observations. Income and population are lagged one year; robust standard errors in parentheses. $* * * \mathrm{p}<0.01, * * \mathrm{p}<0.05, * \mathrm{p}<0.1$.

Columns (1) and (4) of Table 2 display the published logit estimates from Montalvo and Reynal-Querol for the cases of ethnic and religious divisions and their impact on the incidence of civil war, their original dependent variable (PRIOcw) [56]. For their diversity indicators, they find that ethnic polarization outperforms ethnic fractionalization, whereas the religious variables are only significant when introduced jointly in the equation. What the authors do not mention is that the correlation between these indices amounts to the problematic level of 0.95 [58]. The corresponding figure for the measures of ethnic diversity is 0.61 [59]. As it is hard to differentiate between fractionalization and polarization empirically, we argue elsewhere that it is more appropriate to use a dummy variable that captures only the cases of very high polarization [28]. In order to follow MRQ's research strategy as closely as possible, we will nevertheless adopt their specification. 
Columns (2) and (5) use the Uppsala/PRIO conflict data [60] - the same source as MRQ — and the author's original definition of civil war (at least 25 battle-deaths a year plus an accumulated total of at least 1,000 deaths). However, we code the dependent variable as the onset rather than the incidence of armed conflict (PrioCW onset) [61]. Note that we are still using the original diversity measures provided by MRQ. The result table shows that in the regressions using the onset of civil war, Israel and Myanmar are dropped, as the conflicts in those countries began before the time period under consideration, i.e., before 1960. If we avoid the double counting of conflicts that span more than one 5 -year period, the impact of ethnic polarization on the risk of war shrinks and loses its statistical significance [62]. Religious polarization also stops to exert a significant effect on the risk of war once we move to the lower conflict threshold of 25 battle deaths per year (Onset 25), as shown in columns (3) and (6). In accordance with Collier and Hoeffler [12] (but see [63]), primary commodity exports fuel civil war onset as do poverty and population size.

In a next step we turn to our models using country-years rather than 5-year periods. Again, our logit specifications in Table 3 follow MRQ's research design as closely as possible, controlling for the same covariates as the original study [64]. Additionally, we control for time dependence between observations, adopting the solution put forward by Beck et al. [65]. We add a counter for the years of peace a country experiences until an outbreak of war to the regression and also include three natural cubic splines. Admittedly, censoring the consecutive conflict years by focusing on onset rather than incidence reduces the serial correlation between cases. It does not, nevertheless, reduce the dependence over time between the observations of peace [66]. Because we rely on Fearon's [30] encompassing data set in this second set of tests, the analysis now covers 160 countries; 132 of these are included in the ethnic diversity group and 134 in the religious diversity group.

Columns (1) and (4) follow MRQ's design and estimate a regression using civil war incidence as a dependent variable (PrioCW). Note that our dependent variable is based on a more recent version of the Uppsala/PRIO conflict data. It therefore slightly differs from the MRQ indicator. Furthermore, our diversity measures are now based on Fearon [30]. Despite these minor changes our estimations confirm, in the spirit of the original publication by MRQ, that ethnic polarization outperforms ethnic fractionalization as an explanatory variable. However, the religious polarization and fractionalization indices are far from reaching statistical significance and the democracy dummy only exerts a statistically significant negative influence on the incidence of civil war.

In the regressions using onset instead of incidence (see columns (2) and (5)), Israel and Myanmar are once again dropped from the estimation. Changing the dependent variable results in the same findings as before, i.e. neither ethnic nor religious polarization has a significant effect on the risk of civil war onset. However, when we use our alternative definition of civil war onset, and thus concentrate on minor armed conflict (see columns (3) and (6)), ethnic polarization exhibits a significant and positive impact on the onset of internal wars although the size of the coefficient drops considerably. Lowering the threshold for civil wars increases the number of onsets substantially. For instance, Bolivia, Chile, Malaysia, Nigeria, and Spain are all countries that experienced this sort of low-level armed conflict [67]. The results suggest that not only model specification matters, but also the definition of conflict; although this specification does not make a difference with regard to religious diversity (column (6)). 
Table 3. Civil War, Fractionalization and Polarization (One year periods, Logit regressions).

\begin{tabular}{|c|c|c|c|c|c|c|}
\hline & $\begin{array}{c}\text { (1) } \\
\text { PrioCW }\end{array}$ & $\begin{array}{c}(2) \\
\text { PrioCW } \\
\text { Onset }\end{array}$ & $\begin{array}{c}(3) \\
\text { Onset } 25\end{array}$ & $\begin{array}{c}\text { (4) } \\
\text { PrioCW }\end{array}$ & $\begin{array}{c}(5) \\
\text { PrioCW } \\
\text { Onset }\end{array}$ & $\begin{array}{c}(6) \\
\text { Onset } 25\end{array}$ \\
\hline 1GDP & $\begin{array}{l}-0.040 \\
(0.158)\end{array}$ & $\begin{array}{l}-0.350 \\
(0.226)\end{array}$ & $\begin{array}{c}-0.400 * * * \\
(0.126)\end{array}$ & $\begin{array}{c}0.067 \\
(0.159)\end{array}$ & $\begin{array}{l}-0.313 \\
(0.198)\end{array}$ & $\begin{array}{c}-0.462 * * * \\
(0.123)\end{array}$ \\
\hline IPopulation & $\begin{array}{c}0.379 * * * \\
(0.094)\end{array}$ & $\begin{array}{c}0.379 * * * \\
(0.103)\end{array}$ & $\begin{array}{c}0.290 * * * \\
(0.078)\end{array}$ & $\begin{array}{c}0.325 * * * \\
(0.104)\end{array}$ & $\begin{array}{c}0.348 * * * \\
(0.117)\end{array}$ & $\begin{array}{c}0.260 * * * \\
(0.092)\end{array}$ \\
\hline Primexp & $\begin{array}{c}-2.005^{*} \\
(1.205)\end{array}$ & $\begin{array}{c}0.122 \\
(1.173)\end{array}$ & $\begin{array}{c}0.299 \\
(0.867)\end{array}$ & $\begin{array}{l}-1.879 \\
(1.165)\end{array}$ & $\begin{array}{c}0.247 \\
(1.183)\end{array}$ & $\begin{array}{c}0.871 \\
(0.799)\end{array}$ \\
\hline Mountains & $\begin{array}{c}0.005 \\
(0.005)\end{array}$ & $\begin{array}{c}0.002 \\
(0.007)\end{array}$ & $\begin{array}{c}0.003 \\
(0.004)\end{array}$ & $\begin{array}{c}0.008 \\
(0.005)\end{array}$ & $\begin{array}{c}0.003 \\
(0.006)\end{array}$ & $\begin{array}{c}0.003 \\
(0.004)\end{array}$ \\
\hline Noncont & $\begin{array}{c}0.248 \\
(0.383)\end{array}$ & $\begin{array}{c}0.286 \\
(0.435)\end{array}$ & $\begin{array}{c}0.214 \\
(0.269)\end{array}$ & $\begin{array}{c}0.187 \\
(0.388)\end{array}$ & $\begin{array}{c}0.289 \\
(0.438)\end{array}$ & $\begin{array}{c}0.254 \\
(0.279)\end{array}$ \\
\hline Democracy & $\begin{array}{c}-0.457 * \\
(0.261)\end{array}$ & $\begin{array}{l}-0.457 \\
(0.327)\end{array}$ & $\begin{array}{l}-0.185 \\
(0.235)\end{array}$ & $\begin{array}{c}-0.538^{* * *} \\
(0.269)\end{array}$ & $\begin{array}{l}-0.495 \\
(0.337)\end{array}$ & $\begin{array}{l}-0.160 \\
(0.231)\end{array}$ \\
\hline $\begin{array}{l}\text { Ethnic Pol. } \\
\text { (Fearon) }\end{array}$ & $\begin{array}{c}1.849 * * * \\
(0.701)\end{array}$ & $\begin{array}{c}1.057 \\
(0.754)\end{array}$ & $\begin{array}{l}1.050 * * \\
(0.524)\end{array}$ & - & - & - \\
\hline $\begin{array}{c}\text { Ethnic Fract. } \\
\text { (Fearon) }\end{array}$ & $\begin{array}{l}-0.195 \\
(0.665)\end{array}$ & $\begin{array}{l}-0.043 \\
(0.850)\end{array}$ & $\begin{array}{c}0.379 \\
(0.538)\end{array}$ & - & - & - \\
\hline $\begin{array}{l}\text { Religious Pol. } \\
\text { (Fearon) }\end{array}$ & - & - & - & $\begin{array}{l}1.178 \\
(0.946)\end{array}$ & $\begin{array}{l}1.028 \\
(1.274)\end{array}$ & $\begin{array}{l}-0.296 \\
(0.757)\end{array}$ \\
\hline $\begin{array}{l}\text { Religious Fract. } \\
\text { (Fearon) }\end{array}$ & - & - & - & $\begin{array}{l}-1.649 \\
(1.269)\end{array}$ & $\begin{array}{l}-1.272 \\
(1.784)\end{array}$ & $\begin{array}{l}-0.112 \\
(1.016)\end{array}$ \\
\hline Constant & $\begin{array}{l}-2.337 \\
(1.452) \\
\end{array}$ & $\begin{array}{c}-5.958 * * \\
(2.363) \\
\end{array}$ & $\begin{array}{c}-4.238^{* * * *} \\
(1.302) \\
\end{array}$ & $\begin{array}{l}-1.678 \\
(1.461) \\
\end{array}$ & $\begin{array}{c}-5.502 * * * \\
(2.062) \\
\end{array}$ & $\begin{array}{c}-2.531 * \\
(1.321) \\
\end{array}$ \\
\hline Observations & 4999 & 4414 & 4233 & 5048 & 4459 & 4271 \\
\hline $\mathrm{N}^{\circ}$ of countries & 132 & 130 & 130 & 134 & 132 & 132 \\
\hline Pseudo R2 & 0.695 & 0.0973 & 0.0882 & 0.691 & 0.0926 & 0.0792 \\
\hline
\end{tabular}

NOTE: Logit models with either civil war incidences or onset as the dependent variable and country years as observations. Income and population are used with their natural logarithm and lagged one year. We account for duration dependence using peace-years correction and three natural cubic splines calculated with the program BTSCS Data Analysis Utility Version 4.0.4. The results for these variables are not shown. Robust standard errors in parentheses. $* * * \mathrm{p}<0.01, * * \mathrm{p}<0.05, * \mathrm{p}<0.1$

Finally, we estimate the risk of civil war with the help of event history models in Table 4. The starting period is 1960 or the year when a country became independent. Note that the data set includes delayed entries and, for some countries, multiple war onsets [68]. We use exponential proportional hazard models, a standard technique that assumes that the risk of a war onset, given the covariates, remains constant [69]. To further examine the question of incidence $v s$. onset, we use the incidence of minor armed conflicts as dependent variable in models (3) and (7) (Intwar 25). The results shown in Table 4 exhibit the same pattern as described for the logit models in Table 3. 
Whenever incidence is used as the dependent variable, ethnic polarization exhibits a significant and positive impact on civil war, whereas ethnic fractionalization does not (columns (1) and (3)). Yet, an increase in the risk of civil unrest cannot be observed for the conflict indicator that accounts for onsets of smaller civil wars (columns (2) and (4)). Religious heterogeneity, in turn, does not count as an explanatory variable regardless of the definition of the dependent variable, apart from GDP and population, nor do any of the control variables reach conventional levels of significance. This demonstrates that the debate, over which form of diversity affects the risk of war, is not yet settled.

Table 4. Civil War, Fractionalization and Polarization (One year periods, Exponential survival).

\begin{tabular}{|c|c|c|c|c|c|c|c|c|}
\hline & $\begin{array}{c}\text { (1) } \\
\text { PrioCW }\end{array}$ & $\begin{array}{c}(2) \\
\text { PrioCW } \\
\text { Onset } \\
\end{array}$ & $\begin{array}{c}(3) \\
\text { Intwar } 25\end{array}$ & $\begin{array}{c}(4) \\
\text { Onset } 25\end{array}$ & $\begin{array}{c}\text { (5) } \\
\text { PrioCW }\end{array}$ & $\begin{array}{c}(6) \\
\text { PrioCW } \\
\text { Onset }\end{array}$ & $\begin{array}{c}\text { (7) } \\
\text { Intwar } 25\end{array}$ & $\begin{array}{c}\text { (8) } \\
\text { Onset } 25\end{array}$ \\
\hline lGDP & $\begin{array}{l}0.641 * * \\
(0.138)\end{array}$ & $\begin{array}{c}0.681 * * \\
(0.128)\end{array}$ & $\begin{array}{c}0.622 * * * \\
(0.102)\end{array}$ & $\begin{array}{c}0.690 * * * \\
(0.077)\end{array}$ & $\begin{array}{l}0.695^{*} \\
(0.130)\end{array}$ & $\begin{array}{c}0.705 * * \\
(0.109)\end{array}$ & $\begin{array}{c}0.629 * * * \\
(0.089)\end{array}$ & $\begin{array}{c}0.640 * * * \\
(0.063)\end{array}$ \\
\hline 1Population & $\begin{array}{c}1.344 * * * \\
(0.142)\end{array}$ & $\begin{array}{c}1.401 * * * \\
(0.146)\end{array}$ & $\begin{array}{c}1.337 * * * \\
(0.112)\end{array}$ & $\begin{array}{c}1.236 * * * \\
(0.091)\end{array}$ & $\begin{array}{c}1.280 * * \\
(0.135)\end{array}$ & $\begin{array}{c}1.372 * * * \\
(0.154)\end{array}$ & $\begin{array}{c}1.285^{* * *} \\
(0.113)\end{array}$ & $\begin{array}{c}1.210 * * \\
(0.095)\end{array}$ \\
\hline Primexp & $\begin{array}{c}0.259 \\
(0.460)\end{array}$ & $\begin{array}{c}1.047 \\
(1.158)\end{array}$ & $\begin{array}{c}0.347 \\
(0.442)\end{array}$ & $\begin{array}{c}1.326 \\
(1.113)\end{array}$ & $\begin{array}{c}0.416 \\
(0.679)\end{array}$ & $\begin{array}{c}1.113 \\
(1.306)\end{array}$ & $\begin{array}{c}0.734 \\
(0.837)\end{array}$ & $\begin{array}{c}2.261 \\
(1.799)\end{array}$ \\
\hline Noncont & $\begin{array}{l}1.355 \\
(0.602)\end{array}$ & $\begin{array}{l}1.200 \\
(0.442)\end{array}$ & $\begin{array}{c}1.434 \\
(0.498)\end{array}$ & $\begin{array}{c}0.985 \\
(0.260)\end{array}$ & $\begin{array}{c}1.255 \\
(0.574)\end{array}$ & $\begin{array}{c}1.195 \\
(0.452)\end{array}$ & $\begin{array}{c}1.425 \\
(0.488)\end{array}$ & $\begin{array}{c}1.036 \\
(0.276)\end{array}$ \\
\hline Democracy & $\begin{array}{c}0.880 \\
(0.233)\end{array}$ & $\begin{array}{c}0.648 \\
(0.206)\end{array}$ & $\begin{array}{c}1.060 \\
(0.218)\end{array}$ & $\begin{array}{c}0.858 \\
(0.188)\end{array}$ & $\begin{array}{c}0.831 \\
(0.222)\end{array}$ & $\begin{array}{c}0.629 \\
(0.205)\end{array}$ & $\begin{array}{c}1.054 \\
(0.218)\end{array}$ & $\begin{array}{c}0.892 \\
(0.193)\end{array}$ \\
\hline Mountains & $\begin{array}{c}1.002 \\
(0.006)\end{array}$ & $\begin{array}{c}0.999 \\
(0.006)\end{array}$ & $\begin{array}{c}1.002 \\
(0.005)\end{array}$ & $\begin{array}{c}1.000 \\
(0.004)\end{array}$ & $\begin{array}{c}1.005 \\
(0.006)\end{array}$ & $\begin{array}{c}0.999 \\
(0.006)\end{array}$ & $\begin{array}{c}1.005 \\
(0.005)\end{array}$ & $\begin{array}{c}1.001 \\
(0.003)\end{array}$ \\
\hline $\begin{array}{l}\text { Ethnic Fract. } \\
\text { (Fearon) }\end{array}$ & $\begin{array}{c}0.619 \\
(0.563)\end{array}$ & $\begin{array}{c}0.955 \\
(0.788)\end{array}$ & $\begin{array}{c}0.919 \\
(0.685)\end{array}$ & $\begin{array}{c}1.408 \\
(0.700)\end{array}$ & - & - & - & - \\
\hline $\begin{array}{l}\text { Ethnic Pol. } \\
\text { (Fearon) }\end{array}$ & $\begin{array}{c}10.229 * * * \\
(8.028)\end{array}$ & $\begin{array}{c}2.018 \\
(1.488)\end{array}$ & $\begin{array}{c}6.653 * * * \\
(4.462)\end{array}$ & $\begin{array}{c}2.189 \\
(1.061)\end{array}$ & $\begin{array}{c}4.743 \\
(6.561)\end{array}$ & $\begin{array}{c}2.576 \\
(3.111)\end{array}$ & $\begin{array}{c}2.682 \\
(2.807)\end{array}$ & $\begin{array}{c}0.609 \\
(0.436)\end{array}$ \\
\hline $\begin{array}{l}\text { Rel. Pol. } \\
\text { (Fearon) }\end{array}$ & - & - & - & - & $\begin{array}{c}0.135 \\
(0.254) \\
\end{array}$ & $\begin{array}{c}0.384 \\
(0.652)\end{array}$ & $\begin{array}{c}0.261 \\
(0.361)\end{array}$ & $\begin{array}{c}1.314 \\
(1.273)\end{array}$ \\
\hline Observations & 4984 & 4984 & 4984 & 4984 & 5033 & 5033 & 5033 & 5033 \\
\hline $\begin{array}{l}\mathrm{N}^{\circ} \text { of } \\
\text { countries }\end{array}$ & 132 & 132 & 132 & 132 & 134 & 134 & 134 & 134 \\
\hline $\mathrm{N}^{\circ}$ of failure & 651 & 71 & 902 & 142 & 655 & 71 & 916 & 145 \\
\hline LR chi2 & 44.57 & 56.81 & 77.99 & 79.23 & 27.90 & 37.51 & 46.43 & 52.37 \\
\hline Prob $>$ chi 2 & 0.000 & 0.000 & 0.000 & 0.000 & 0.000 & 0.000 & 0.000 & 0.000 \\
\hline
\end{tabular}

NOTE: Coefficients in the table are estimated using exponential survival regression and report the estimated multiplicative effect of a one-unit change in the independent variable on the mean time until failure (Hazard ratios). Income and population are used with their natural logarithm. Robust standard errors in parentheses. $* * * \mathrm{p}<0.01, * * \mathrm{p}<0.05, * \mathrm{p}<0.1$.

Such a caveat is also in line with studies focusing on the impact that diversity has on the magnitude of war. Using a dichotomous measure of polarization, Lacina [70], for instance, shows that polarized societies experience less rather than more severe civil conflicts, measured by the number of battle 
deaths. We believe that this correlation needs a sound theoretical basis, as it is in contrast to the theoretical finding of Esteban and Ray [25] and the empirical evidence assembled by Montalvo and Reynal-Querol [52]. These contrasting findings show that the field should move away from attempts to establish one facet of diversity, like polarization as the core variable, which proves superior for the explanation of all sorts of political violence. While it may be sensibly linked to the duration of wars, it is, in our view, not a good explanation for the onset of conflict as two equally strong groups can sensibly deter each other from using force. It seems, moreover, more interesting to explore the interaction of diversity with the institutional setting for the explanation of various social outcomes. This is especially relevant as many young democracies still experiment with varying constitutional recommendations.

\section{Diversity and Economic Growth: Empirical Patterns}

Diversity is also often linked to the development of a country. Our final test looks at the relationship between diversity and economic growth. Our re-calculations presented here suggest additional ambiguities that the future study of diversity has to take into account. We estimate the average annual growth rate of GDP per capita per decade and control with dummy variables for the decades (1960, 1970, and 1980) and a data set of 160 countries. In accordance with Easterly and Levine, we employ seemingly unrelated regression as a method to causally link development to civil war (for details see [7]) [71]. Since religious polarization and fractionalization are highly correlated, we do not use both variables together in the growth regressions.

We are able to replicate the Easterly and Levine results almost one to one, although there are minor differences in the magnitude of the estimated coefficients. The most striking difference is that, in almost all models, the dummy for Sub-Saharan Africa does not exhibit a statistically significant effect. Furthermore, the variable for average educational attainment, the log of schooling, is significant in the models containing what Easterly and Levine call policy variables, i.e., in the models in columns (3), (4), (7) and (8). Financial depth always shows a positive influence on long-run growth, but, contrary to the original article, reaches statistical significance. In agreement with the original study, ethnic fractionalization always exerts a negative influence on growth. Interestingly, the effect of ethnic polarization runs into the opposite direction, but is not statistically significant in the baseline model (see also Valsecchi [53]). This means, in contrast to Montalvo and Reynal-Querol [6], extreme ethnic divisions translate into increased rather than decreased economic growth, which renders the idea plausible that a high level of competition between highly visible and thus identifiable groups might be good for the economic prospects of a country [73].

In models, including the so-called policy variables, the magnitude of the ethnic polarization and fractionalization coefficients rises. Ethnic polarization is now highly significant, regardless of whether religious fractionalization or religious polarization is added. The latter variable exerts a significant and positive influence only in the model that takes into account the proxy variable for public policy; an indicator that counts telephones per worker confirming findings by Alesina et al. [31]. 
Table 5. Fractionalization, polarization and economic development.

\begin{tabular}{|c|c|c|c|c|c|c|c|c|}
\hline & $\begin{array}{l}\text { (1) } \\
\text { gyp }\end{array}$ & $\begin{array}{l}(2) \\
\text { gyp }\end{array}$ & $\begin{array}{l}\text { (3) } \\
\text { gyp }\end{array}$ & $\begin{array}{l}\text { (4) } \\
\text { gyp }\end{array}$ & $\begin{array}{l}\text { (5) } \\
\text { gyp }\end{array}$ & $\begin{array}{l}\text { (6) } \\
\text { gyp }\end{array}$ & $\begin{array}{l}\text { (7) } \\
\text { gyp }\end{array}$ & $\begin{array}{l}\text { (8) } \\
\text { gyp }\end{array}$ \\
\hline \multirow[t]{2}{*}{ Dummy 1960s } & -0.066 & -0.090 & -0.099 & -0.084 & -0.081 & -0.107 & -0.117 & -0.113 \\
\hline & $(0.092)$ & $(0.093)$ & (0.109) & $(0.111)$ & $(0.092)$ & (0.093) & $(0.108)$ & (0.109) \\
\hline \multirow[t]{2}{*}{ Dummy 1970s } & -0.069 & -0.092 & -0.096 & -0.078 & -0.084 & -0.109 & -0.113 & -0.107 \\
\hline & $(0.092)$ & (0.093) & (0.109) & $(0.110)$ & $(0.092)$ & (0.093) & (0.108) & (0.109) \\
\hline \multirow[t]{2}{*}{ Dummy 1980s } & -0.088 & -0.112 & -0.112 & -0.094 & -0.103 & -0.128 & -0.129 & -0.122 \\
\hline & $(0.092)$ & (0.093) & $(0.109)$ & $(0.110)$ & $(0.092)$ & (0.093) & (0.108) & $(0.109)$ \\
\hline \multirow[t]{2}{*}{ Dummy SSA } & -0.006 & -0.007 & -0.005 & -0.010 & -0.009 & $-0.011^{*}$ & -0.008 & $-0.014 * *$ \\
\hline & $(0.005)$ & $(0.005)$ & $(0.006)$ & $(0.006)$ & $(0.006)$ & $(0.006)$ & $(0.006)$ & (0.006) \\
\hline Dummy Latin & $-0.019 * * *$ & $-0.019 * * *$ & $-0.014^{* * *}$ & $-0.017 * * *$ & $-0.019 * * *$ & $-0.018 * * *$ & $-0.013 * * *$ & $-0.016^{* * *}$ \\
\hline America/Carrib & $(0.004)$ & (0.004) & $(0.004)$ & $(0.004)$ & $(0.004)$ & $(0.004)$ & $(0.004)$ & $(0.004)$ \\
\hline Log of initial & 0.030 & 0.037 & 0.045 & $0.050 *$ & 0.034 & $0.041^{*}$ & $0.049^{*}$ & $0.057 * *$ \\
\hline income & $(0.024)$ & $(0.024)$ & $(0.028)$ & $(0.028)$ & $(0.024)$ & $(0.024)$ & $(0.028)$ & $(0.028)$ \\
\hline Log of initial & -0.002 & $-0.003 *$ & $-0.004 * *$ & $-0.005 * * *$ & $-0.003^{*}$ & $-0.003 * *$ & $-0.004 * *$ & $-0.006 * * *$ \\
\hline income 2 & $(0.002)$ & $(0.002)$ & $(0.002)$ & $(0.002)$ & $(0.002)$ & $(0.002)$ & $(0.002)$ & $(0.002)$ \\
\hline $\log$ of & $0.012 * * *$ & $0.012 * * *$ & $0.013 * * *$ & $0.009 *$ & $0.011 * *$ & $0.011 * * *$ & $0.012 * * *$ & $0.008^{*}$ \\
\hline schooling & $(0.004)$ & $(0.004)$ & $(0.005)$ & $(0.005)$ & $(0.004)$ & $(0.004)$ & $(0.005)$ & $(0.005)$ \\
\hline \multirow[t]{2}{*}{ Assassinations } & - & $-24.631 * *$ & $-25.208 * * *$ & $-29.581 * * *$ & - & $-26.986^{* *}$ & $-26.879 * * *$ & $-31.554 * * *$ \\
\hline & & (10.512) & (9.486) & (8.904) & & (10.568) & $(9.450)$ & $(8.831)$ \\
\hline \multirow[t]{2}{*}{ Financial depth } & - & - & $0.023 * * *$ & $0.019 * *$ & - & - & $0.023 * * *$ & $0.019 * *$ \\
\hline & & & $(0.008)$ & $(0.008)$ & & & $(0.008)$ & $(0.007)$ \\
\hline \multirow{2}{*}{$\begin{array}{l}\text { Black market } \\
\text { premium }\end{array}$} & - & - & $-0.021 * * *$ & $-0.020 * * *$ & - & - & $-0.022 * * *$ & $-0.020 * * *$ \\
\hline & & & (0.004) & $(0.004)$ & & & (0.004) & (0.004) \\
\hline \multirow{2}{*}{$\begin{array}{l}\text { Fiscal surplus/ } \\
\text { GDP }\end{array}$} & - & - & $0.077 * *$ & $0.166^{* * * *}$ & - & - & $0.082 * * *$ & $0.172 * * *$ \\
\hline & & & $(0.031)$ & $(0.036)$ & & & $(0.031)$ & $(0.036)$ \\
\hline \multirow{2}{*}{$\begin{array}{l}\text { Log telephones } \\
\text { per worker }\end{array}$} & - & - & - & $0.010 * * *$ & - & - & - & $0.010 * * *$ \\
\hline & & & & $(0.003)$ & & & & $(0.003)$ \\
\hline \multirow{2}{*}{$\begin{array}{l}\text { Ethnic Fract. } \\
\text { (Fearon) }\end{array}$} & $-0.025^{* *}$ & $-0.028 * * *$ & $-0.045^{* * *}$ & $-0.045 * * *$ & $-0.027 * * *$ & $-0.030 * * *$ & $-0.044 * * *$ & $-0.043 * * *$ \\
\hline & $(0.010)$ & $(0.010)$ & $(0.012)$ & $(0.012)$ & $(0.010)$ & $(0.010)$ & $(0.012)$ & $(0.012)$ \\
\hline \multirow{2}{*}{$\begin{array}{l}\text { Ethnic Pol. } \\
\text { (Fearon) }\end{array}$} & 0.008 & 0.012 & $0.028 * * *$ & $0.036^{* * *}$ & 0.008 & 0.011 & $0.026 * * *$ & $0.034 * * *$ \\
\hline & $(0.008)$ & $(0.008)$ & $(0.009)$ & $(0.009)$ & $(0.008)$ & $(0.008)$ & (0.009) & $(0.009)$ \\
\hline \multirow{2}{*}{$\begin{array}{l}\text { Rel. Fract. } \\
\text { (Fearon) }\end{array}$} & -0.009 & -0.005 & 0.004 & 0.001 & - & - & - & - \\
\hline & $(0.008)$ & (0.008) & (0.009) & $(0.008)$ & & & & \\
\hline \multirow{2}{*}{$\begin{array}{l}\text { Rel. Pol. } \\
\text { (Fearon) }\end{array}$} & - & - & - & - & 0.003 & 0.006 & 0.011 & $0.011^{*}$ \\
\hline & & & & & $(0.007)$ & $(0.007)$ & $(0.007)$ & $(0.006)$ \\
\hline Observations & 253 & 250 & 183 & 169 & 253 & 250 & 183 & 169 \\
\hline $\mathrm{N}^{\circ}$ of id & 92 & 92 & 76 & 71 & 92 & 92 & 76 & 71 \\
\hline Wald chi2 & 242.1 & 251.9 & 278.8 & 383.3 & 238.6 & 252.0 & 287.8 & 399.7 \\
\hline Prob > chi2 & 0.000 & 0.000 & 0.000 & 0.000 & 0.000 & 0.000 & 0.000 & 0.000 \\
\hline
\end{tabular}

NOTE: Growth Regressions: Pooled Decades (1960s, 1970s, 1980s). Estimated using xtgee in Stata for Seemingly Unrelated Regression with unbalanced equations: a separate regression for each period. Standard errors in parentheses. $* * * \mathrm{p}<0.01, * * \mathrm{p}<0.05, * \mathrm{p}<0.1$. 


\section{Conclusion}

Speculations on the impact of diversity on social outcomes abound due to the growing heterogeneity of many societies around the world. Some publications have fuelled the concern that increasing diversity bodes badly for these countries. A most notable case is Huntington's [2] essay on the "Clash of Civilizations". Analytically, there are different possibilities in which we can think about the impact that diversity has on social outcomes. We believe that empirical research has not been sufficiently careful in developing causal mechanisms that link one particular facet of diversity to one particular social outcome. In other words, while fragmentation might lower the risk of one form of violence, it can increase the propensity of another form of violence; and while polarization might affect economic development given a certain institutional configuration, it might not do so in all contexts. We therefore believe that the field should move away from a simplifying understanding of diversity that links one of its many manifestations, be it polarization or fractionalization, to all sorts of social dysfunctions like armed conflict and underdevelopment [74].

We have used recent controversies and the role played by fractionalization or polarization to illustrate that the empirical study of diversity needs better theories and, in some instances, better indicators and data. Future studies should for instance use refined measures of polarization that truly differentiate this concept from fractionalization at the empirical level. Although we have ample reason to believe that polarization increases the risk of various forms of violence [17], we also need to look more carefully into the role that political institutions play in this context [24,28]. Political sociologists have for a long time recognized that institutions are partly a response to social divisions. Yet, the rules that guide the interactions between competing groups are not completely determined by the social fabric surrounding them. On the contrary, institutions exert a significant impact on social relations on their own. In democratic regimes, for instance, the structure of party systems is of utmost importance [6]. Therefore, we consider a careful consideration of context specific explanations to be a promising avenue for future research. The theoretical and empirical exploration of the joint impact that institutions, economic factors and diversity have on social processes seems particularly farsighted to us.

\section{Acknowledgements}

We would like to thank Joan Esteban, James D. Fearon, Nils Petter Gleditsch, Gudrun Østby and three reviewers for comments on a previous draft. We also gratefully acknowledge the able research assistance by Sonja Hämmer. This paper is part of the Polarization and Conflict Project CIT-2-CT-2004-506084 funded by the European Commission-DG Research Sixth Framework Programme. This article reflects only the authors' views and the Community is not liable for any use that may be made of the information contained therein.

\section{References and Notes}

1. Page, S.E. The Difference. How the Power of Diversity Creates Better Groups, Firms, Schools, and Societies; Princeton University Press: Princeton, NJ, USA, 2007.

2. Huntington, S.P. The Clash of Civilizations and the Remaking of the World Order; Simon and Schuster: New York, NY, USA, 1997. 
3. Russett, B.; Oneal, J.; Cox, M. Clash of civilizations, or realism and liberalism déjà vu? some evidence. J. Peace Res. 2000, 37, 583-608.

4. Neumayer, E.; Plümper, T. Terrorism and the clash of civilization. Was Huntington right after all? Brit. J. Polit. Sci. 2009, 39, 711-734.

5. Montalvo, J.G.; Reynal-Querol, M. Ethnic polarization, potential conflict, and civil wars. Am. Econ. Rev. 2005, 95, 796-813.

6. Montalvo, J.G.; Reynal-Querol, M. Ethnic diversity and economic development. J. Dev. Econ. 2005, 76, 293-323.

7. Easterly, W.; Levine, R. Africa's growth tragedy: Policies and ethnic divisions. Q. J. Econ. 1997, 112, 1203-1250.

8. Hirschman, A.O. The paternity of an index. Am. Econ. Rev. 1964, 54, 761-762.

9. Collier, P. Implications of ethnic diversity. Econ. Policy 2001, 32, 127-166.

10. Alesina, A.; La Ferrara, E. Ethnic diversity and economic performance. J. Econ. Lit. 2005, 43, 762-800.

11. Ellingsen, T. Colorful community or ethnic witches' brew? Multiethnicity and domestic conflict during and after the cold war. J. Conflict Resolut. 2000, 44, 228-249.

12. Collier, P.; Hoeffler, A. Greed and grievance in civil war. Oxford Econ. Pap. 2004, 56, 563-595.

13. Hegre, H.; Ellingsen, T.; Gates, S.; Gleditsch, N.P. Toward a democratic civil peace? Democracy, political change, and civil war, 1816-1992. Am. Polit. Sci. Rev. 2001, 95, 33-48.

14. Fearon, J.D.; Laitin, D.D. Ethnicity, insurgency, and civil war. Am. Polit. Sci. Rev. 2003, 97, 75-90.

15. Hegre, H.; Sambanis, N. Sensitivity analysis of empirical results on civil war onset. J. Conflict Resolut. 2006, 50, 508-535.

16. Esteban, J.; Ray, D. On the measurement of polarization. Econometrica 1994, 62, 819-851.

17. Esteban, J.; Ray, D. Conflict and distribution. J. Econ. Theory, 1999, 87, 379-415.

18. Duclos, J.Y.; Esteban, J.; Ray, D. Polarization: Concepts, measurement, estimation. Econometrica 2004, 72, 1737-1772.

19. For the case of discrete distributions in which the data comes in groups of observations (like the number of votes by political parties in an election) one can use the polarization index in Esteban and Ray [16], which is the discrete analogue of the index presented above.

20. Wolfson [21] and Wang and Tsui [22] have proposed alternative measures of polarization which capture the formation of two poles and hence should better be denoted measures of "bi-polarization".

21. Wolfson, M.C. When inequalities diverge. Am. Econ. Rev. 1994, 84, 353-358.

22. Wang, Y.Q.; Tsui, K.Y. Polarization orderings and new classes of polarization indices. J. Public Econ. Theory 2000, 2, 349-363.

23. Reynal-Querol, M. Ethnicity, Political systems, and civil wars. J. Conflict Resolut. 2002, 46, 29-54.

24. Reynal-Querol, M. Does democracy preempt civil wars? Eur. J. Polit. Econ. 2005, 21, 445-465.

25. Esteban, J.; Ray, D. Polarization, fractionalization and conflict. J. Peace Res. 2008, 45, 163-182.

26. Zagare, F.C.; Kilgour, D.M. Perfect Deterrence (Cambridge Studies in International Relations); Cambridge University Press: Cambridge, UK, 2000. 
27. Verwimp, P. The political economy of coffee, dictatorship, and genocide. Eur. J. Polit. Econ. 2003, 19, 161-181.

28. Schneider, G.; Wiesehomeier, N. Rules that matter. Political institutions and the polarization-conflict nexus. J. Peace Res. 2008, 45, 183-203.

29. Soviet Union, Glavnoe upravlenie geodezii i kartografii. Atlas Novogo Mira; Bruk, S.I., Apenchenko, V.S., Eds.; GUGK: Moscow, USSR, 1964.

30. Fearon, J.D. Ethnic and cultural diversity by country. J. Econ. Growth 2003, 8, 195-222.

31. Alesina, A.; Devleeschauwer, A.; Easterly, W.; Kurlat, S.; Wacziarg, R. Fractionalization. J. Econ. Growth 2003, 8, 155-194.

32. Cederman, L.-E.; Wimmer, A.; Min, B. Why do ethnic groups rebel? New data and analysis. World Polit. 2010, 62, 87-119.

33. Vanhanen, T. Domestic ethnic conflict and ethnic nepotism: A comparative analysis. J. Peace Res. 1999, 36, 55-73.

34. Relying on this data set, we are able to find the same empirical relationship between our measures of polarization and fractionalization as MRQ. For the sake of brevity, these figures are not included.

35. The correlation between our ethnic polarization measure and the one used by Montalvo-Reynal-Querol is 0.8 , the correlation between our ethnic fractionalization measure and their indicator reaches the same level. For religious diversity, however, the correlation between our measures of religious fractionalization and polarization and those of MRQ are in both cases only around 0.5 .

36. Wuthnow, R. The Encyclopedia of Politics and Religion; Routledge: London, UK, 1998; Volume 1.

37. Inglehart, R.; Norris, P. Sacred and Secular. Religion and Politics Worldwide; Cambridge University Press: New York, NY, USA, 2004.

38. Haynes, J. Religion, Fundamentalism, and Ethnicity: A Global Perspective; UNRISD Discussion Paper 65; UNRISD: Geneva, Switzerland, 1995.

39. Kuper, A.; Kuper, J. The Social Science Encyclopedia; Routledge: London, UK, 1996; Volume 2.

40. Herskovits [41] even considered syncretism as a concept for specifying the degree to which diverse cultures have integrated.

41. Herskovits, M. The Myth of the Negro Past; Beacon: Boston, MA, USA, 1958.

42. Brazilian Candombles, Greenfield ([42], p. 116) reasons that there has been "convergence of significant aspects of Yoruba beliefs and practices and the Roman Catholicism of Luso-Brazilians".

43. Greenfield, S.M. The reinterpretation of Africa: Convergence and syncretism in Brazilian candomble. In Reinventing Religions: Syncretism and Transformation in Africa and the Americas; Greenfield, S.M., Droogers, A., Eds.; Rowman and Littlefield: Lanham, MD, USA, 2001; pp. 113-118.

44. Lynch, C. Dogma, praxis, and religious perspectives on multiculturalism. Millennium-J. Int. Stud. 2000, 29, 741-759.

45. Droogers, A. Syncretism and fundamentalism: A comparison. Soc. Compass 2005, 52, 463-471.

46. Lambropoulos, V. Syncretism as mixture and as method. J. Mod. Greek Stud. 2001, 19, 221-235. 
47. Encyclopedia Britannica, 15th ed.; Encyclopædia Britannica Inc.: Chicago, IL, USA, 2002.

48. Claffey, P. The Place of the 'imaginaire religieux' in social change and political recomposition in sub-Saharan Africa. Antrophos 2001, 96, 200-206.

49. Beck, N. Modeling dynamics in the study of conflict: A comment on Oneal and Russett. In Globalization and Armed Conflict; Schneider, G., Barbieri, K., Gleditsch, N.P., Eds.; Rowman and Littlefield: Lanham, MD, USA, 2003; pp. 165-177.

50. Elbadawi, I.; Sambanis, N. How much war will we see? Explaining the prevalence of civil war. J. Conflict Resolut. 2002, 46, 307-334.

51. Brandt, P.; Manson, D.; Gurses, M.; Petrovski, N.; Radin, D. When and how the fighting stops: Explaining the duration and outcome of civil wars. Defence Peace Econ. 2008, 19, 415-434.

52. Montalvo, J.G.; Reynal-Querol, M. Ethnic polarization and the duration of civil wars. Econ. Governance 2010, 11, 123-143.

53. Valsecchi, M. Ethnic diversity, economic performance and civil wars. In Working Papers in Economics; No. 433; University of Gothenburg, School of Business, Economics and Law: Gothernburg, Sweden, 2010.

54. As an additional test we ran the models using MRQ's original dependent variable and exchanged only the diversity measures. When we use the ethnicity measures based on Fearon data, unfortunately the cases drop from 846 to 824, but MRQ's main findings remain the same. In the case of the religious measure, the measure that differs most from MRQ's, the cases do not drop as dramatically (from 846 to 830), but now these variables do not matter for civil war incidence. We also used the diversity measures based on Alesina et al. [31]. In that case sample, cases are as in the original publication and neither ethnicity nor religious diversity measures do matter for civil war incidence.

55. The appendix to this article summarizes the operational definitions and the sources of the data.

56. We cross-checked our logit models in two ways. First, we used the relogit command in Stata to control for the rare event character of very violent wars (see [57]). Second, we relied on generalized estimation equations (GEE) with a binomial distribution and a one-year time lag for the autocorrelation structure. To reassess the results from our exponential survival regression, we also estimated semiparametric Cox proportional hazard models with GDP and Population as time-varying covariates. The results did not differ substantively from those reported here and are available upon request. Additionally, for all our models and robustness checks we used fractionalization and polarization measures based on the data of Alesina et al [30]. With this alternative resource, polarization never exhibits a significant positive impact on civil war, whatever specification of the dependent variable we use.

57. King, G.; Zeng, L. Logistic regression in rare events. Polit. Anal. 2001, 9, 137-163.

58. In the case of the religious measures the authors do consider this problem in Montalvo and Reynal-Querol [6] and use these indices separately, whereas in Montalvo and Reynal-Querol [5] they do not. Alesina et al. [31] already hint at this problem in their article and demonstrate that the polarization index works best when highly correlated with the fractionalization measure.

59. Our ethnic fractionalization and the ethnic polarization index based on Fearon exhibit a correlation of 0.65 , our religious fractionalization and religious polarization measures one of 0.88 . 
60. Gleditsch, N.P.; Wallensteen, P.; Eriksson, M.; Sollenberg, M.; Strand, H. Armed conflict 1946-2001: A new dataset. J. Peace Res. 2002, 39, 615-637.

61. There are minor deviations, as we use a more recent version of this data set (Version 3.0) than MRQ (Version unknown). The correlation between our incidence variable and the one used by MRQ amounts to 0.96 .

62. Fearon [63] hints at the problem that dropping periods of ongoing war is artificially increasing the mean of the dependent variable and proposes as a "natural alternative" to code them as zeros. Applying this approach to all our replication models (including those in Table 1) does not affect our results substantially.

63. Fearon, J.D. Primary commodity exports and civil war. J. Conflict Resolut. 2005, 49, 483-507.

64. To simplify the presentation of the covariates in the Table, but still distinguish the 5-year periods from the country-year data, we use the same abbreviations, but not in capitals as in the original publication. See appendix for sources of the yearly data.

65. Beck, N.; Katz, J.N.; Tucker, R. Taking time seriously: Time-Series-Cross-Section analysis with a binary dependent variable. Am. J. Polit. Sci. 1998, 42, 1260-1288.

66. Beck, Katz and Tucker have constructed an algorithm that can be used in this context. Available online: http://www.prio.no/CSCW/Datasets/Stata-Tools/ (accessed on 31 March 2010). The splines are tied together at certain knots, which we place at the years 1, 4, and 7 following the suggestion from Beck, Katz, and Tucker [65]. A significance test of the cubic splines indicates the need to correct for duration dependence.

67. Likewise, this pattern persisted with our dummy variable of ethnic polarization. In the case of minor armed conflict, the variable always had a positive, statistically significant influence on the onset of civil war.

68. The event history models using onset include the cases of Israel and Myanmar, treating them as censored cases.

69. As mentioned above, we also used the less restrictive semi-parametric Cox proportional hazard model.

70. Lacina, B. Explaining the severity of civil wars. J. Conflict Resolut. 2006, 50, 276-289.

71. Since in Stata the command for seemingly unrelated regression is not suitable for estimation with unbalanced panels, thus resulting in loss of information, we use the xtgee command with a Gaussian family, an identity link, and an unstructured within-group correlation structure [72]

72. McDowell, A. From the help desk: Seemingly unrelated regression with unbalanced equations. Stata J. 2004, 4, 442-448.

73. The ethnic diversity measures based on Alesina show the same relationship for the growth regressions as our indices based on Fearon. However, note that the interpretation of the effects as laid out in Easterly and Levine [7] is not warranted anymore since we include the diversity measures together in the regressions for illustrative purposes.

74. The concern for causal explanations in the social sciences has attracted increasing interest. See Falleti and Lynch [75] especially for a discussion of context embeddedness.

75. Falleti, T.G.; Lynch, J. Context and causal mechanisms in political analysis. Comp. Polit. Stud. 2009, 42, 1143-1166. 


\section{Appendix}

With the exception of the variable for the onset of civil war, all variables from Table 1 are taken from MRQ`s original dataset (see Montalvo and Reynal-Querol [40] for details). Tables 2 and 3 put the MRQ study within a country-year frame using the same covariates (for details, see below). Table 5 uses original data from Easterly and Levine [18] (see [18] for detailed explanations) with additional information on ethnic and religious divisions using the Fearon data.

PrioCW: Our analyses focus on internal and internationalized internal conflicts and are thus limited to disputes that are located in the country of reference (type 3 and 4). We generated a dichotomous variable, i.e., the conflict indicator is 1 if the incompatibility results in at least 25 battle-related deaths per year and an accumulated total of at least 1,000 deaths. This is equivalent to the intermediate armed conflict and war definition of the Uppsala/PRIO armed conflict data set (Gleditsch et al. [24]).

PrioCW Onset: Same as PrioCW dropping all subsequent years of an ongoing conflict to capture the onset of civil war.

Intwar 25: Definition of minor armed conflict of the Uppsala/PRIO armed conflict data set. Again we concentrate on type 3 and 4 incompatibilities. The dummy variable is 1 if the threshold of 25 battle-related deaths has been crossed for the first time and 0 if no internal civil war has started in the year under consideration.

Onset 25: Same as Intwar 25 dropping all subsequent years of an ongoing conflict.

GDP: logged and lagged one year. Source: Fearon and Laitin [23]. To avoid systematic missings, we extrapolated the year 2000 where appropriate. As there have not been any major economic distortions in 2000 , this should not cause any problems. Note also that the correlation of this variable with the one used by MRQ is 0.999 for their country sample.

Population: Country-year population, logged and lagged one year. Source: Fearon and Laitin [23]. To avoid systematic missings, we extrapolated the years 1999 and 2000 under the condition that at least eight consecutive country years of observations before 1999 were available. Again, the correlation between this variable and the one used by MRQ is 0.997 for their country sample.

Primexp: Primary commodity exports as proportion of GDP. Country-year version of the Collier and Hoeffler data [10] taken from Fearon [23], denoted there sxp.

Mountains: Estimated percentage of mountainous terrain based on the on work by the geographer A. J. Gerard for the World Bank's "Economics of Civil War, Crime, and Violence" project. Fearon and Laitin add twenty-two countries to this list. Source: Fearon and Laitin [23].

Noncont: Noncontiguous states are countries with territory holding at least 10,000 people and separated from the land area containing the capital city either by land or by 100 kilometers of water. Source: Fearon and Laitin [23].

Democracy: General openness of the political institutions $(0=$ low, $10=$ high $)$ from the Polity IV dataset. Like MRQ, we construct a dummy variable that takes the value 1 if the score is higher or equal to 4 .

Ethnic Fractionalization: We use a measure from Fearon [21] who relied on the Encyclopedia Britannica, the CIA's World Factbook and other sources. The fractionalization index ranges from 0 to 1 . 
Ethnic Polarization: Our ethnic polarization measure, which is based on a list of ethnic groups per country from Fearon [21], was calculated using the RQ formula.

Religious Fractionalization: We use a measure from Fearon [21]. The fractionalization index ranges from 0 to 1 .

Religious Polarization: Our measure is based on data about religious groups per country kindly provided by James. D. Fearon. R. Quinn Mecham used the CIA Factbook and several other sources to construct a list of adherents per country. Our measure was calculated using the RQ formula.

(C) 2010 by the authors; licensee MDPI, Basel, Switzerland. This article is an open access article distributed under the terms and conditions of the Creative Commons Attribution license (http://creativecommons.org/licenses/by/3.0/). 